\title{
Younger Customers' Outlooks when Selecting and Changing a Financial Services Provider: The Case of Maltese Students
}

\author{
Silvio John Camilleri ${ }^{1} \&$ Denise Ellul ${ }^{1}$ \\ ${ }^{1}$ Banking and Finance Department, Faculty of Economics, Management \& Accountancy, University of Malta, Msida, \\ Malta \\ Correspondence: Silvio John Camilleri, Banking and Finance Department, Faculty of Economics, Management \& \\ Accountancy, University of Malta, Msida MSD 2080, Malta.
}

Received: January 22, 2017

Accepted: February 13, 2017

Online Published: February 28, 2017

doi:10.5430/ijfr.v8n2p51

URL: http://dx.doi.org/10.5430/ijfr.v8n2p51

\begin{abstract}
In order for banks to supplement their market share, it is crucial for them to entice new customers such as students who are expected to join the workforce at a subsequent stage. The main aim of this paper is to survey the banks' tactics in this regard, the response of students to such schemes, and the aspects which such customers consider when selecting a particular service provider or when switching to another one. We conduct interviews with bank representatives and distribute questionnaires to first year university students in order to gauge whether particular factors are more important than others in the selection of a financial services provider. We find that there are various aspects which banks may leverage upon to entice potential customers to switch away from competing service providers, especially due to the fact that switchers tend to respond differently to given characteristics in their decision making process.
\end{abstract}

Keywords: bank marketing, customer loyalty, Malta, retail banking, students' bank accounts, young customers

\section{Introduction}

As the banking sector evolved and as banks shifted from mass marketing approaches towards designing their products to suit particular segments, this resulted in improvements in marketing efficiency and customer service. Banks are devoting increased importance on attracting students since these constitute a central component of a potentially-lucrative market. Banks realise that this segment may become tomorrow's business people, and therefore they do their utmost to draw as many students as possible. Students are also considered important since they are likely to account for a substantial proportion of the young adult population and the latter is more likely to adopt innovations at an early stage (Morris and Venkatesh, 2000; Rogers, 2003).

Notwithstanding that initially banks are likely to incur a net cost through offering packages to students, over the longer term these customers may become highly lucrative ones. In this way the overall profitability of enticing younger customers through special packages, may depend on the loyalty of these people (Colgate et. al., 1996). Opening a student's account is considered as an initial step towards retaining custom and loyalty. Customer loyalty proves even more important when considering that attracting a new client is often more costly than retaining an existing one.

The main aim of this paper is to assess banks' strategies targeted at student customers, the corresponding response on part of such potential customers and the factors which may entice students to select a particular service provider or to switch to another one. We therefore conducted interviews with bank representatives, and distributed questionnaires to first year university students, in order to gauge which factors tend to be more important than others, and to assess whether loyal and switching clients respond differently to given features. Distinguishing between the latter types of customers contributes towards understanding the intricacies of customer heterogeneity, as found in prior literature such as Foscht et. al. (2009) and Al-hawari (2015).

The paper is structured as follows: Section 2 offers a review of prior literature, and the third section outlines the methodology. We present a background to the Maltese banking market and the insights from the interviews with bank representatives in Section 4. In Section 5 we summarise the questionnaire outcomes and distinguish between the responses of switchers and non-switchers to investigate what characteristics may be more relevant to entice these 
particular groups. Section 6 concludes.

\section{Contextual Background and Prior Literature}

\subsection{Student Packages Offered by Banks}

Banks offer different services that could be relevant to both students and school leavers, and product packages are considered as potential triggers to life-long banking relationships. Banks may also serve as a point of reference to students who have little knowledge about financial affairs, since they may guide them to financial planning by offering them basic services. Usually the first savings which students set aside emanate from pocket money or from gifts on part of parents. For instance according to The Master Card Foundation (2012), young adults in various countries received money as gifts from relatives or acquaintances. As young adults move away from their parental home, this implies further commitments and therefore a demand for additional financial products (Child and Youth Finance International and MasterCard, 2014).

Current accounts and savings accounts tend to be widely popular among students, since these offer immediate access to funds and are ideal for transactional needs. Different student packages typically add on supplementary features such as debit cards or credit cards which may be made available at reduced fees. Savings electronic accounts are widely popular amongst students since money can be managed more conveniently (Diaz, 2013) and possibly attract preferential interest rates.

Students who develop a good track record are normally allowed to apply for a credit card. Students are more likely to avail themselves of credit cards if they have higher purchasing power, if they need credit, when they are lured by incentives, and if they percieve that they are getting a good customer service (Blankson et. al. 2012). Overdrafts constitute another flexible way of borrowing smaller sums to generate extra liquidity and these usually constitute an added benefit packaged with other accounts.

Banks may also offer student loans which are designed to finance educational expenses such as books, tuition and computers. Personal loans may also be made available; for instance to finance car purchases. Lending banks would usually require these borrowers to have any income directly credited to the same bank for the purpose of more effective monitoring. Loans offered to mature students are normally priced at preferential rates and they do not always entail a collateral. Given this, banks would rely on the students' track record and trustworthiness.

Banks and other entities often take broader initiatives targeted specifically at younger age groups. In Greece, Alpha Bank designed the ALPHA 1|2|3 bank account which represents the three stages of youth (i.e. childhood, teenage and young adulthood). This product was intended to entice parents to open an account for their children, to be used until the latter reach the age of 27 (Alpha Bank, 2014). In Thailand, the Government Savings Bank sponsors a school bank project, which involves a model bank operated by students aged between nine and fifteen. The main aim is to promote savings among students and to offer them a trial opportunity to manage finances. Similar initiatives are being taken in other countries as well (Masa et. al. 2010).

In order to encourage students to open their first account with the institution or to renew their custom, banks may offer gift incentives. This stance is at times used in order to entice students to switch banks when they already hold a relationship with another service provider. Gifts offered by banks include insurance discounts, store discount cards, travel cards, and reduced commissions on foreign currency exchange (Waters, 2006).

One should also note that the student population served by banks is likely to comprise international students who may differ in their needs and expectations about bank services (Bond and Hsu, 2011). Given this, one should not think of this market segment as a homogeneous constituent.

\subsection{Bank Selection Decisions, Loyalty and Switching Tendencies}

The bank selection decision on part of students is a function of different factors. These include perceived security (Gerrard and Cunningham, 1997; Mokhlis et. al., 2008), service quality (Chigamba and Fatoki, 2011), availability of electronic services (Katircioglu et. al., 2011; Rashid, 2012), and convenience (Gerrard and Cunningham, 1997; Rao and Sharma, 2010). Prior literature such as Martenson (1985) suggests that students are also influenced by their parents' choices when selecting a particular financial services provider and according to the World Economic Forum (2013) the millennial generation is even more likely than other age categories to rely on the recommendations from family and friends. Despite this, Almossawi (2001) found that recommendations from acquaintances ranked amongst the least important factors impacting on bank selection decisions by college students in Bahrain.

The likelihood of a customer swapping banks increases if expectations are not met by a service provider, and this is an additional reason why banks segment their customer base and offer products which are aimed particularly at 
designated groups. Customers who feel inappropriately served by banks are likely to create adverse publicity for the institution. Colgate et. al. (1996) reported that reducing students' defection rates can have substantial impacts on bank profitability since low defection rates make it easier to recoup the initial costs involved in attracting students.

Prior literature identified different factors which impinge on customer loyalty. Service quality is one such determinant and this may be assessed through observing overall reliability (Camilleri et. al, 2013), efficiency (Jun and Cai, 2001), and staff competence. Rashid (2012) reported that the latter was an important aspect which impinged on the service provider selection decision of university students in Bangladesh. According to Al-hawari (2015) the relationship between service quality and customer loyalty may be partly dependent on personality characteristics such as emotional stability and extraversion.

Customer satisfaction also impacts on customer loyalty (Ehigie, 2006; Ndubisi and Wah, 2005). Satisfied customers are not only likely to be repeat-clients but they may also recommend the service provider to acquaintances (Hossain and Lee, 2009; Yavas et. al., 2004). Prior literature such as Ayo et. al. (2016), Paul et. al. (2016), and Sayani (2015) suggests that customer satisfaction is a function of an array of factors such as the relationship with the service provider, service delivery, and pricing. The latter was found to be an important factor in bank selection decisions on part of Hong Kong students (Chan, 1993) and Indian bank customers (Kaura et. al, 2015).

Image is another determinant of customer loyalty. Image is not only a function of the efforts of service providers, but also of the intertemporal judgements by customers and potential customers. Narteh and Owusu-Frimpong (2011) found that bank image was influential on the bank selection choices of students in Ghana and on whether they retained their relation with the same institution. As one may expect, determinants of customer loyalty are not independent; for instance the image of a service provider is partially reliant on customer satisfaction (Bloemer and Odekerken-Schroder, 2002). In a survey conducted amongst students from Ghana, Narteh (2013) found that the image of the bank, satisfaction with the bank's offering, and electronic bank services contribute to customer loyalty.

Afsar et. al. (2010) discussed the concept of false loyalty where dissatisfied customers remain loyal to their current service provider due to the costs and inconvenience associated with migrating to another bank. Switching costs may be significant in banking, for instance when shifting a loan facility across banks or when customers have acquired a bundle of products from a given entity.

Vyas and Raitani (2014) investigated the switching patterns of different bank customers in India. They reported that switching behaviour is shaped by factors such as convenience in terms of opening hours and ATM networks, responses of bank staff and relationship aspects. Conversely factors such as interest rates, branch location and trust proved less important. Saleem et. al. (2016) found that in order to instil customer loyalty, banks should emphasise social influence factors (since consumers are more prone to peer and group influence when acquiring complex products), marketing orientation (responding efficiently and effectively to customer needs), and service quality.

Prior research such as Foscht et. al. (2009) reports that loyalty and switching patterns differ across age groups, and that the contributors towards customer satisfaction change during different stages in life. This suggests that the relative importance of the former factors is somewhat fluid.

\section{Methodology}

In the process of collecting primary data for this study, we commenced by conducting semi-structured interviews with marketing personnel from Bank Of Valletta, HSBC Bank (Malta), Banif Bank, and APS Bank. The main scope of the interviews was to highlight whether banks consider students as an important market segment and the competitive positioning tactics which they emphasise in order attract this customer category.

We also circulated a questionnaire among tertiary students residing in Malta. The questionnaire was intended to yield an insight into students' attitudes towards bank offerings and the factors that entice them to select and to change their service provider. The questionnaires were completed by first-year university students aged over eighteen, studying at various faculties at the University of Malta which is the main tertiary educational institution in the country. In order to make it easier for respondents to complete the questionnaire and to make the data more adaptable to quantitative analysis, most questions required a response in terms of selecting a particular reply or ranking amongst alternative options.

Before distributing the questionnaires, a pilot study was conducted amongst seven respondents to identify any possible flaws in the draft version. The questionnaire was subsequently amended to clarify some shortcomings, and the responses from the pilot study were not included in the final sample. Over 3,000 questionnaires were sent by email through the Registrar's Office of the University of Malta. We obtained 345 responses which represent a response rate of $11.3 \%$. 
The questionnaire was sub divided in two sections. The first part sought information about the respondents' age and gender. The second section concerned the factors that influence students to choose a particular bank, their perceptions about bank services, whether they changed their bank in the past, the possibility that they switch banks in the future, and the reasons behind such choices.

In analysing the questionnaire responses we laid emphasis on the differences between students who switched their service provider in the past, and those who never did so. We thus grouped all relevant responses under broad categories, to investigate whether switchers and non-switchers respond differently to particular attributes such as range of services, reputation and price factors.

\section{The Management of Students' Accounts by Maltese Banks}

Despite being a small island, Malta has a dynamic retail banking market which is characterised by the activity of about seven banks, out of more than 25 which operate in the country. The assets held by the Maltese banking sector at the end of 2015 totalled Euro 46.7 billion, and $43 \%$ of them were held by the core domestic banks which offer the bulk of retail banking services (Malta Financial Services Authority Annual Report, 2015). The main portion of the retail market activity is undertaken by Bank of Valletta and HSBC Bank (Malta). In general, banks follow prudent management policies and given their sound financial standing (Camilleri, 2005), they were not largely impacted by the financial crisis which started in 2007 (Briguglio et. al., 2009). Indeed, Malta ranks fifteenth out of 140 countries in terms of the soundness of the banking system (World Economic Forum, 2015).

Maltese banks offer special packages to students at tertiary and post-secondary levels. These students typically receive government stipends which are credited directly to their bank accounts. In addition, students receive a maintenance grant which is a one-time payment intended to alleviate expenses incurred when purchasing books and other educational requisites. Given this financial assistance, Maltese students do not typically request credit facilities from banks when studying at a home-country institution. The meagre demand for student loans when some form of government aid is available is noticeable in other countries such as the US (Todd, 2013).

We now summarise the insights obtained through the interviews conducted with marketing personnel from four Maltese banks. It transpired that banks emphasise different factors through which they seek a competitive positioning. Some of them focus on upholding their brand promise of understanding customer needs and offering solutions through simple-to-use services. Other banks' selling points range from being part of an internationally renown group to a more flexible and customer centric service owing to the small size of the institution. All interviewees mentioned that their institution considers retail banking to be the most important revenue source.

All the interviewed banks market products or packages which are aimed particularly at students. In some cases, these accounts may be opened as early as at the age of thirteen. Some banks also offer credit facilities for older students. These include general overdrafts and loans to finance further studies or to start-up a business. Interest-paying savings accounts constitute a popular product amongst students and these are usually coupled with a debit card and online banking facilities. Current accounts usually incorporate a cheque book facility and therefore banks may be more cautious when offering such services to students. Student packages usually comprise advantageous terms such as better interest rates and free standing orders.

Banks are aware that young customers are unlikely to generate profits in the immediate term, however they acknowledge that they can become important revenue-generators at subsequent stages. Young customers are thus considered in the context of a possible longer-term relationship since these are likely to demand credit facilities or investment services in the future. Indeed, in an effort to attract such customers, one particular bank established a scheme where students who introduce a new client are awarded a monetary gift.

Banks adopt a blend of tactics in order to reach the student population such as retaining an online presence and visits to educational institutions. It also seems that banks are becoming more cost-conscious and therefore emphasising internet use for the purpose of more cost-efficient publicity. One particular institution uses up-to-date social media communication to attract young customers and usually refrains from being present at educational institutions during the initial scholastic weeks when other banks are actively marketing on location. Banks also use market influencer strategies such as featuring popular personalities in their adverts to entice young customers towards the bank's offers.

Banks are aware that gifts may be the starting point of a life-long relationship and therefore they offer free technology peripherals, vouchers or cash payments to new student customers at the start of the academic year. Most interviewees were of the opinion that such gifts do influence the potential customers' choice of bank. These offers are used to attract as many first year student accounts as possible, since the tendency is that students would not usually change their service provider unless they are dissatisfied with the service or a significantly better offer is proposed by a peer institution. 
Banks realise that most students set up accounts in the banks used by their immediate family members, and gifts constitute an attempt to counter such tendencies. Some banks also offer further gifts when students renew the direct credit of their stipend in the subsequent years of their studies. Banks identify the gifts to be offered after they conduct research through focus groups, competitor analysis, questionnaires and surveys. One interviewee recounted an episode which occurred in 2005 when a bank replaced gifts with a promise of contributions towards a particular environmental initiative. In that instance the bank witnessed a substantial reduction of new student accounts. When gifts were reintroduced the following year, the number of new students' accounts rose again.

\section{Questionnaire Findings}

In this section we analyse the responses from the questionnaires completed by first-year students across all faculties of the University of Malta. The questionnaire was answered by 345 respondents whose ages and gender are shown in Table 1. The majority of participants were studying at the Faculty of Economics, Management, and Accountancy.

Table 1. Respondents by age group and gender

\begin{tabular}{lcc}
\hline & Response Count & $\%$ \\
18 to 19 & 175 & $50.7 \%$ \\
20 to 22 & 110 & $31.9 \%$ \\
$23+$ & 60 & $17.4 \%$ \\
& & \\
Females & 236 & $68.4 \%$ \\
Males & 109 & $31.6 \%$
\end{tabular}

Note: The table shows the categorisation of the questionnaire respondents by age and gender.

Table 2. The Importance of banks for students

\begin{tabular}{lc}
\hline & Average Ranking \\
Banks offer safe-keeping of funds & 1.75 \\
Banks offer lending facilities & 2.65 \\
Banks pay interest on deposits & 2.71 \\
Banks offer financial advice and related services & 2.90 \\
\hline
\end{tabular}

Note: Students were asked to rank the reasons why they think that banks are important. A ranking of 1 denoted the most important factor and a ranking of 4 denoted the least important factor. The average rankings are shown in the second column.

As shown in Table 2, most students associate the general importance of banks in society with the fact that these offer services related to the safe-keeping of savings. $81 \%$ of the respondents stated that the main reason for holding a bank account is the direct credit of stipends (Table 3). This may be due to the fact that most people require basic services at a relatively young age, although it may also indicate a lack of awareness about supplementary services which banks typically offer.

Table 3. Perceived usefulness of bank services

\begin{tabular}{lcc}
\hline & Response Count & $\%$ \\
Facilitating the direct credit of income and payments & 239 & $81.0 \%$ \\
Helping to control and track spending patterns & 187 & $63.4 \%$ \\
Offering customized packages & 93 & $31.5 \%$ \\
Paying interest on deposits & 77 & $26.1 \%$ \\
Cheaper availability of credit & 72 & $24.4 \%$ \\
Others (e.g. paying for goods purchased online) & 17 & $5.8 \%$ \\
\hline
\end{tabular}

Note: The table reports the reasons why bank services are perceived as useful. Respondents could select up to three different options, and therefore the percentages do not add up to 100 . 
Table 4 shows the criteria considered by respondents when selecting their main bank account provider. Bank reputation proved the most important aspect, followed by recommendations by family members. Respondents rated advertising campaigns as the least influential in this regard, although one does not exclude the possibility that advertising plays a more subliminal impact on consumer decision-making - such as reinforcing the reputation and perceived reliability of an institution.

Table 4. Rating of the overall influence when selecting the main service provider

\begin{tabular}{lccc}
\hline & Sum of Ratings & Median Rating & Mode Rating \\
Bank reputation & 353 & Influential & Strongly Influential \\
Family recommendations & 291 & Influential & Strongly Influential \\
Internet bank facilities & 210 & Influential & Influential \\
Range of services & 179 & Influential & Influential \\
Knowledgeable / helpful staff & 166 & Influential & Influential \\
Mobile banking facilities & 107 & Neutral & Neutral \\
Gift incentives & 98 & Neutral & Influential \\
Favourable interest rates & 96 & Neutral & Neutral \\
Range of credit / debit cards & 76 & Neutral & Neutral \\
Recommendations by friends & -5 & Neutral & Neutral \\
Advertising campaigns & -6 & Neutral & Neutral \\
\hline
\end{tabular}

Note: Respondents were asked to rate the respective influence of the factors shown in the first column. "Strongly Influential" and "Influential" ratings were assigned 2 points and 1 point respectively. The "Neutral" rating was assigned 0 points, and "Non-Influential" and "Strongly Non-Influential" were assigned -1 point and -2 points respectively. The rating in the second column was computed by adding up the total points for each option; a higher score indicating a higher overall influence. The third column shows the median rating and the fourth column shows the mode rating (i.e. the most frequently chosen rating).

Respondents were also asked to select a favourite bank (not necessarily their current service provider) and then they were asked to indicate the criteria according to which they chose a particular institution (Table 5). Reputation and influence from third parties were the most commonly chosen options ( $77.6 \%$ and $51.0 \%$ of respondents respectively), and this is in line with the top influence rankings shown in Table 4. Only $5.4 \%$ of students stated that they based their decision on the fees charged by banks. Again, the latter may be due to the fact that at this stage students demand the most basic services, which banks do not typically charge any fees in respect of.

Table 5. Criteria considered when choosing a particular "favourite bank"

\begin{tabular}{lcc}
\hline & Response Count & $\%$ \\
Bank reputation & 228 & $77.6 \%$ \\
Influence from other people & 150 & $51.0 \%$ \\
Range of banking facilities & 116 & $39.5 \%$ \\
Better interest rates & 111 & $37.8 \%$ \\
Attractive free gifts & 60 & $20.4 \%$ \\
Customized packages & 37 & $12.6 \%$ \\
Discounted fees & 16 & $5.4 \%$ \\
\hline
\end{tabular}

Note: Respondents were first asked to choose a particular "favourite bank" from a range of options, and then they were asked to select up to three of the above criteria on which their former decision was based. Given that respondents could choose more than one option, percentages do not add up to 100. 
Table 6. Reasons why respondents changed banks in the past

\begin{tabular}{lcc}
\hline & Response Count & $\%$ \\
Expectations of better customer service & 38 & $42.7 \%$ \\
Others (e.g. employer's requirements) & 35 & $39.3 \%$ \\
Suggestions by family or friends & 26 & $29.2 \%$ \\
Lower fees & 25 & $28.1 \%$ \\
Gifts offered by other institutions & 18 & $20.2 \%$ \\
More favourable interest rates & 16 & $18.0 \%$
\end{tabular}

Note: Respondents who changed their bank service provider were asked the reasons behind their decision. Given that switchers could choose up to three options, the percentages do not add up to 100 .

Table 7. Factors enticing respondents to consider changing their bank

\begin{tabular}{lcc}
\hline & Response Count & $\%$ \\
Better customised packages offered elsewhere & 51 & $68.0 \%$ \\
Expectations of a better customer service & 31 & $41.3 \%$ \\
Influence by family or friends & 24 & $32.0 \%$ \\
Others (e.g. more ATM facilities, reputation) & 13 & $17.3 \%$ \\
Better interest rates offered elsewhere & 12 & $16.0 \%$ \\
Expectations of lower charges & 11 & $14.7 \%$ \\
Gifts offered by other banks & 6 & $8.0 \%$
\end{tabular}

Notes: Respondents who were considering changing their institution were asked the reasons behind this possible decision. Given that more than one option could be selected, percentages do not add up to 100.

The percentages reported in this table are different from the related ones reported in Table 9. In this table, percentages were computed as a proportion of respondents who were considering changing their bank. In Table 9 percentages are reported as a proportion of the number of switchers and/or non-switchers.

$27.2 \%$ of the respondents indicated that they had switched from one bank to another and the reasons for doing so included expectations of better customer service (42.7\% of switchers) or employers requiring internship students to have their stipends credited to accounts held with a particular service provider (grouped under the "Other" category). $29.2 \%$ of the switchers indicated that they changed their service provider in line with suggestions of families or friends (Table 6).

Table 8. Reasons for holding a secondary account with another banking institution

\begin{tabular}{lrr}
\hline & Response Count & $\%$ \\
Establishing a track record for future need (e.g. obtaining credit facilities) & 55 & $45.1 \%$ \\
Establishing a relationship with another bank & 51 & $41.8 \%$ \\
Diversification purposes & 39 & $32.0 \%$ \\
Influence by relatives or friends & 27 & $22.1 \%$ \\
Others (e.g. accounts opened in a different country of residence) & 20 & $16.4 \%$ \\
Gifts offered by banks upon opening an account & 18 & $14.8 \%$
\end{tabular}

Notes: Respondents who opened a second bank account with a different institution were asked the reasons behind their decision. Given that more than one option could be selected, percentages do not add up to 100.

The percentages reported in this table are different from the related ones reported in Tables 9 and 10. In this table, percentages were worked out as a proportion of respondents who opened a secondary account. In Tables 9 and 10 percentages are reported as a proportion of the number of switchers and/or non-switchers. 
Table 9. Panel A: Observations relating to overall customer service and product range attributes

\begin{tabular}{|c|c|c|c|}
\hline \multirow[b]{2}{*}{$\begin{array}{l}\text { - Respondents influenced by range of services when } \\
\text { choosing their main service provider }\end{array}$} & \multicolumn{3}{|c|}{$\%$ of sub-category } \\
\hline & $\begin{array}{l}\text { Non-Switchers } \\
55.0 \%\end{array}$ & $\begin{array}{c}\text { Switchers } \\
65.2 \%\end{array}$ & $\begin{array}{c}\text { All } \\
57.8 \%\end{array}$ \\
\hline $\begin{array}{l}\text { - Respondents influenced by range of credit cards when } \\
\text { choosing their main service provider }\end{array}$ & $35.3 \%$ & $57.3 \%$ & $41.3 \%$ \\
\hline $\begin{array}{l}\text { - Respondents influenced by internet banking facilities } \\
\text { when choosing their main service provider }\end{array}$ & $56.7 \%$ & $68.5 \%$ & $59.9 \%$ \\
\hline $\begin{array}{l}\text { - Respondents influenced by mobile banking facilities } \\
\text { when choosing their main service provider }\end{array}$ & $42.9 \%$ & $55.1 \%$ & $46.2 \%$ \\
\hline $\begin{array}{l}\text { - Respondents influenced by perceived helpfulness of staff } \\
\text { when choosing their main service provider }\end{array}$ & $52.9 \%$ & $67.4 \%$ & $56.9 \%$ \\
\hline $\begin{array}{l}\text { - Respondents who think that bank accounts are vital since } \\
\text { they give access to customised packages }\end{array}$ & $34.7 \%$ & $22.8 \%$ & $31.5 \%$ \\
\hline $\begin{array}{l}\text { - Respondents considering changing their bank in search } \\
\text { of better customer service }\end{array}$ & $7.6 \%$ & $14.6 \%$ & $9.5 \%$ \\
\hline $\begin{array}{l}\text { - Respondents considering changing their bank in search } \\
\text { of better customised packages }\end{array}$ & $12.6 \%$ & $23.6 \%$ & $15.6 \%$ \\
\hline $\begin{array}{l}\text { - Respondents who selected a particular "favourite bank" } \\
\text { on the basis of range of banking facilities }\end{array}$ & $38.1 \%$ & $43.0 \%$ & $39.5 \%$ \\
\hline $\begin{array}{l}\text { - Respondents who selected a particular "favourite bank" } \\
\text { on the basis of customised packages }\end{array}$ & $11.6 \%$ & $15.2 \%$ & $12.6 \%$ \\
\hline $\begin{array}{l}\text { t Statistic on the Null Hypothesis of No Difference betwee } \\
\text { Non-Switchers (Paired Means Test) }\end{array}$ & Switchers and & & \\
\hline 99\% Critical Value (one-tailed test) & & & \\
\hline
\end{tabular}

Note: The overall difference between switchers and non-switchers for the above group of factors is significant at the $99 \%$ level of confidence when considering a one-tailed paired two-sample t-test on means.

$77.0 \%$ of the respondents were not planning to switch their banking institution. As shown in Table 7, the main reasons why the other respondents were considering to change their main service provider, were a perceived better customised package offered elsewhere (68.0\%) and expectations of a better customer service $(41.3 \%)$.

The majority of the sampled respondents $(61.8 \%)$ do not have a secondary account with another bank. As shown in Table 8, the most common reasons for opening a secondary bank account were to establish a track record with another bank for possible future need or to establish a new relationship with another bank ( $45.1 \%$ and $41.8 \%$ of those who hold a secondary bank account respectively). The initial gifts offered by banks were the least influential in this regard.

The final stage of analysing the questionnaire data, consisted of distinguishing between the responses of the participants who changed their bank services provider in the past (switchers) and those who never changed their service provider (non-switchers). We thus re-organised the questionnaire observations under three broad categories concerning: (a) overall customer service and product range attributes, (b) reputation of the bank and recommendations from acquaintances, and (c) price-related factors such as interest rates and fees (Table 9: Panels A-C). Where the questionnaire observations could not be grouped under any of these three categories, these were not included in this part of the analysis. We then conducted paired t-tests on means to check whether the differences in the responses of switchers and non-switchers were statistically significant. 
Table 9. Panel B: Observations relating to bank reputation and acquaintances' recommendations

\begin{tabular}{|c|c|c|c|}
\hline \multirow[b]{2}{*}{$\begin{array}{l}\text { - Respondents influenced by bank reputation when } \\
\text { choosing their main service provider }\end{array}$} & \multicolumn{3}{|c|}{$\%$ of sub-category } \\
\hline & $\begin{array}{l}\text { Non-Switchers } \\
76.9 \%\end{array}$ & $\begin{array}{c}\text { Switchers } \\
76.4 \%\end{array}$ & $\begin{array}{c}\text { All } \\
76.8 \%\end{array}$ \\
\hline $\begin{array}{l}\text { - Respondents influenced by family recommendations when } \\
\text { choosing their main service provider }\end{array}$ & $72.3 \%$ & $59.6 \%$ & $68.8 \%$ \\
\hline $\begin{array}{l}\text { - Respondents influenced by friends' recommendations } \\
\text { when choosing their main service provider }\end{array}$ & $34.0 \%$ & $27.0 \%$ & $32.1 \%$ \\
\hline $\begin{array}{l}\text { - Respondents influenced by advertising campaigns when } \\
\text { choosing their main service provider }\end{array}$ & $38.2 \%$ & $28.1 \%$ & $35.5 \%$ \\
\hline $\begin{array}{l}\text { - Respondents who opened a secondary bank account due to } \\
\text { influence from acquaintances }\end{array}$ & $8.0 \%$ & $9.0 \%$ & $8.3 \%$ \\
\hline $\begin{array}{l}\text { - Respondents considering changing their bank due to } \\
\text { recommendations from acquaintances }\end{array}$ & $5.9 \%$ & $11.2 \%$ & $7.3 \%$ \\
\hline $\begin{array}{l}\text { - Respondents who selected a particular "favourite bank" on } \\
\text { the basis of reputation }\end{array}$ & $81.4 \%$ & $67.1 \%$ & $77.6 \%$ \\
\hline $\begin{array}{l}\text { - Respondents who selected a particular "favourite bank" on } \\
\text { the basis of influence from other people }\end{array}$ & $60.9 \%$ & $24.1 \%$ & $51.0 \%$ \\
\hline $\begin{array}{l}\text { t Statistic on the Null Hypothesis of No Difference between } \\
\text { Non-Switchers (Paired Means Test) }\end{array}$ & Switchers and & 2.0 & \\
\hline 95\% Critical Value (one-tailed test) & & 1.8 & \\
\hline
\end{tabular}

Note: The overall difference between switchers and non-switchers for the above group of factors is significant at the $95 \%$ level of confidence when considering a one-tailed paired two-sample t-test on means.

The results suggest that switchers tend to be more responsive to customer service and product range attributes and this difference is significant at the 99\% level of confidence (Table 9: Panel A). Non-switchers tend to be more influenced by bank reputation and recommendations and this difference is significant at the $95 \%$ level of confidence (Table 9: Panel B). When considering price-related factors, switchers are more influenced by this aspect and the overall difference in responses is significant at the $90 \%$ level of confidence (Table 9: Panel C).

Overall, it transpires that switchers tend to be influenced by tangible and easily-quantifiable factors (product attributes, interest rates and fees) whereas non-switchers are more receptive to intangibles (such as reputation and recommendations). This suggests that banks should adopt a variety of factors as sources of competitive leverage if they aim to attract both of these types of customers. In particular, the more tangible factors should be emphasised to promote customer loyalty since the results show that switchers were relatively more influenced by these factors when they changed their service provider.

Table 9. Panel C: Observations concerning price-related factors: interest rates and fees

\begin{tabular}{|c|c|c|c|}
\hline \multirow[b]{3}{*}{$\begin{array}{l}\text { - Respondents influenced by favourable interest rates } \\
\text { when choosing their main service provider }\end{array}$} & \multicolumn{3}{|c|}{$\%$ of sub-category } \\
\hline & Non-Switchers & Switchers & All \\
\hline & $43.3 \%$ & $51.7 \%$ & $45.6 \%$ \\
\hline $\begin{array}{l}\text { - Respondents who think that bank accounts are vital } \\
\text { since they offer interest on deposits }\end{array}$ & $29.2 \%$ & $17.7 \%$ & $26.1 \%$ \\
\hline $\begin{array}{l}\text { - Respondents who think that bank accounts are vital } \\
\text { since they make it cheaper to obtain credit }\end{array}$ & $23.6 \%$ & $26.6 \%$ & $24.4 \%$ \\
\hline $\begin{array}{l}\text { - Respondents who opened a secondary bank account to } \\
\text { establish a track record with another bank * }\end{array}$ & $10.1 \%$ & $34.8 \%$ & $16.8 \%$ \\
\hline $\begin{array}{l}\text { - Respondents considering changing their bank in search } \\
\text { of more advantageous interest rates }\end{array}$ & $4.2 \%$ & $2.2 \%$ & $3.7 \%$ \\
\hline
\end{tabular}




\begin{tabular}{lccc}
\hline $\begin{array}{l}\text { - Respondents considering changing their bank in search } \\
\text { of lower charges }\end{array}$ & $1.7 \%$ & $7.9 \%$ & $3.4 \%$ \\
$\begin{array}{l}\text { - Respondents who selected a particular "favourite bank" } \\
\begin{array}{l}\text { on the basis of better interest rates } \\
\text { - Respondents who selected a particular "favourite bank" }\end{array}\end{array} \quad 23.0 \%$ & $50.6 \%$ & $37.8 \%$ \\
\hline
\end{tabular}
on the basis of discounted fees

t Statistic on the Null Hypothesis of No Difference between Switchers and Non-Switchers (Paired Means Test) 90\% Critical Value (one-tailed test)

Notes: The overall difference between switchers and non-switchers for the above group of factors is significant at the $90 \%$ level of confidence when considering a one-tailed paired two-sample t-test on means.

* We included this observation under this category on account that people might want to establish a track record with another bank in order to be able to bargain for more advantageous terms. If this observation is excluded, the difference between the responses of switchers and non-switchers for this group of factors would no longer be statistically significant.

\section{Conclusion}

Prior literature suggests that there is a tendency for new bank customers to select the same financial services provider serving other family members (Martenson, 1985; World Economic Forum, 2013). Therefore when institutions aim to enlarge their market share, it is crucial for them to entice customers whose relatives do not have a relationship with their institution. In this context, the findings of this paper are particularly relevant since they point at various factors which banks may leverage upon to retain existing student customers and to entice potential ones who are considering switching away from competing service providers.

In view of prior research which suggests that customer loyalty may be partly dependent on age categories (Foscht et. al., 2009) and individual personality characteristics (Al-hawari, 2015) our findings are also pertinent when formulating marketing policies targeted at younger customers, since they yield further insight into the diversity of this age bracket. An additional way in which this paper addresses the intricacy of client heterogeneity, is that it distinguishes between customers who switched their service provider in the past and those that remained loyal to their bank.

The interviewed bank representatives reported that institutions are aware that students may present lucrative potential in the long run despite that they may not prove profitable in the shorter term. All the sampled banks offer products or packages which are aimed particularly at students. Banks are aware that students are inclined to set up accounts with the same service providers used by other family members and this trend also emerged in the questionnaires completed by first-year students at the University of Malta where the importance of influence on part of relatives is evident.

$27.2 \%$ of the respondents indicated that they had changed their financial services provider due to various reasons including the expectations of better customer service (Table 6). $77 \%$ of the respondents were not planning to switch their banking institution, and those considering doing so were enticed by a perceived better customised package offered elsewhere and the expectations of better customer service (Table 7). This is in line with prior literature which highlights the importance of service quality (Hossain and Lee, 2009; Yavas et. al., 2004) and customer satisfaction (Ehigie, 2006; Ndubisi and Wah, 2005).

Banks seek to establish a competitive position over peers through customised packages, target advertising, gifts, and visits to educational institutions. Online marketing is becoming increasingly important due to its efficacy and cost-effectiveness. Collectively, these elements may be considered as an attempt on part of banks to counter the tendency for new customers to select the same service provider which is used by immediate family members.

Students' responses reveal that bank reputation and recommendations from family or acquaintances rank amongst the top factors on which they base their service provider decision (Tables 4 and 5). The relevance of reputation is in line with prior research such as Almossawi (2001), yet the author also reported that recommendations from friends and relatives ranked rather low in the bank selection decision. 
The importance of reputation and recommendations may be associated with the fact that new customers have only limited familiarity with service providers and therefore they give weight to suggestions from acquaintances rather than drawing on their own personal experiences. Indeed, when the decision shifts to changing an existing financial services provider, the influence by family members is then preceded by customer service expectations given that clients may then rely on first-hand occurrences (Table 6).

Despite that respondents rated gifts as a low-to-moderate influential factor, the empirical incident of a sharp drop in new students accounts which was experienced when a bank substituted the typical gift scheme with a societal contribution, suggests that gifts are still a relevant component in the overall offering (Tables 4-8 and Section 4).

When distinguishing between the questionnaire responses of switchers and non-switchers, it emerged that switchers are more influenced by customer service and product range attributes and this difference is significant at the $99 \%$ level of confidence (Table 9: Panel A). Switchers are also more receptive to advantageous interest rates and lower fees (Table 9: Panel C). Non-switchers devote more importance to bank reputation and recommendations from acquaintances and this difference is significant at the $95 \%$ level of confidence (Table 9: Panel B).

In this way, it transpires that switchers tend to be influenced by tangible and easily-quantifiable factors such as product attributes, interest rates and fees. These factors are therefore important to dissuade existing customers from migrating to other banks, and to entice switchers who are migrating from competing institutions. Conversely, non-switchers are more receptive to intangibles, including reputation and recommendations and overall these aspects seem more relevant in attracting customers who are new to the banking markets since they have to rely on such aspects given their limited personal experiences in financial affairs. This suggests that there is a variety of factors which influence the choice of a financial service provider and the subsequent loyalty on part of student customers. It is also evident that people who switched their service provider in the past differ in terms of the respective importance which they devote to distinct criteria.

The findings that these respective sub-categories tend to emphasise different factors in their selection decisions, are relevant for banks that would like to sharpen their strategies to satisfy better their customer needs. In doing this, banks are likely to reap rewards in terms of repeat business and recommendations to further potential customers (Hossain and Lee, 2009; Yavas et. al., 2004). In addition, the former insights into the behaviour of switching customers and the motives behind their switching decision, may help banks to reduce customer defection rates; as reported in prior studies this can have substantial impacts on profitability through expediting the recouping of the initial costs involved in attracting students (Colgate et. al., 1996).

Therefore, further studies may be conducted on the how banks can design marketing tactics featuring a mixture of the features discussed in this paper, targeted particularly at specific categories of potential customers or existing ones. The potential for further research seems even more noteworthy when considering that the relative importance of different selection criteria on part of students can vary across countries as found by Blankson et. al. (2007).

\section{Acknowledgements}

The authors thank the management of APS Bank, Banif Bank, Bank of Valletta, and HSBC Bank (Malta) for their interview responses, the Registrar's Office at the University of Malta for forwarding the questionnaires, and all the respondents.

\section{References}

Afsar, B., Rehman, Z., Qureshi, J.A., \& Shahjehan, A. (2010). Determinants of customer loyalty in the banking sector: The case of Pakistan. African Journal of Business Management, 4(6), 1040-1047.

Al-hawari, M.A. (2015). How the personality of retail bank customers interferes with the relationship between service quality and loyalty. International Journal of Bank Marketing, 33(1), 41-57. http://dx.doi.org/10.1108/IJBM-09-2013-0096

Almossawi, M. (2001). Bank selection criteria employed by college students in Bahrain: An empirical analysis. International Journal of Bank Marketing, 19(3), 115-125. http://dx.doi.org/10.1108/02652320110388540

Alpha Bank. (2014). Alpha 1|2|3| Youth Line. Retrieved from http://www.alpha.gr/page/default.asp?la=2\&id=145

Ayo, C.K., Oni, A.A., Adewoye, O.J., \& Eweoya, I.O. (2016). E-banking users' behaviour: E-service quality, attitude, and customer satisfaction. International Journal of Bank Marketing, 34(3), 347-367. http://dx.doi.org/10.1108/IJBM-12-2014-0175

Blankson, C., Cheng, J.M-S., \& Spears, N. (2007). Determinants of banks selection in USA, Taiwan and Ghana. 
International Journal of Bank Marketing, 25(7), 469-489. http://dx.doi.org/10.1108/02652320710832621

Blankson, C., Paswan, A., \& Boakye, K.G. (2012). College students' consumption of credit cards. International Journal of Bank Marketing, 30(7), 567-585. http://dx.doi.org/10.1108/02652321211274327

Bloemer, J., \& Odekerken-Schroder, G. (2002). Store satisfaction and store loyalty explained by customer and store-related factors. Journal of Consumer Satisfaction. Dissatisfaction and Complaining Behavior, 15(11), 68-80. Retrieved from http://hdl.handle.net/2066/142940

Bond, C., \& Hsu, M. (2011). International Students' Perceptions of Service Quality in the UK Banking Sector: An Exploratory Study. Journal of International Students, 1(2), 50-58.

Briguglio, L., Antoniou, A., Cordina, G., \& Farrugia, N. (2009). The Maltese and Cypriot economies: Weathering the global recession. Conference on Sustaining Development in Small States in a Turbulent Global Economy; Commonwealth Secretariat, Marlborough House: London.

Camilleri, S.J. (2005). An analysis of the profitability, risk and growth indicators of banks operating in Malta. Bank of Valletta Review, 31(1), 32-48. https://www.bov.com/documents/bov-review-31-paper-3

Camilleri, S.J., Cortis, J., \& Fenech, M.D. (2013). Service quality and internet banking: Perceptions of Maltese retail bank customers. Bank of Valletta Review, 48(2), 1-17. Retrieved from https://www.bov.com/documents/bov-review-48-paper-1

Chan, R.Y.W. (1993). Banking services for young intellectuals. International Journal of Bank Marketing, 11(5), 33-40. http://dx.doi.org/10.1108/02652329310039636

Chigamba, C., \& Fatoki, O. (2011). Factors influencing the choice of commercial banks by university students in South Africa. International Journal of Business and Management, 6(6), 66-76. http://dx.doi.org/10.5539/ijbm.v6n6p66

Child and Youth Finance International \& MasterCard Incorporated International. (2014). Banking a new generation. CYFI Secretariat, Amsterdam, The Netherlands.

Colgate, M., Stewart, K., \& Kinsella, R. (1996). Customer defection: A study of the student market in Ireland. International Journal of Bank Marketing, 14(3), 23-29. http://dx.doi.org/10.1108/02652329610113144

Diaz, C. (2013). Money Boot Camp: Financial Literacy for teens. PYP Publishing Group, US.

Ehigie, B.O. (2006). Correlates of customer loyalty to their bank: A case study in Nigeria. International Journal of Bank Marketing, 24(7), 494-508. http://dx.doi.org/10.1108/02652320610712102

Foscht, T., Schloffer, J., Maloles III, C., \& Chia, SL. (2009). Assessing the outcomes of Generation-Y customers' loyalty. International Journal of Bank Marketing, 27(3), 218-241. http://dx.doi.org/10.1108/02652320910950204

Gerrard, P., \& Cunningham, B. (1997). Islamic banking: A study in Singapore. International Journal of Bank Marketing, 15(6), 204-216. http://dx.doi.org/10.1108/02652329710184433

Hossain, M., \& Lee, S. (2009). Customer perception on service quality in retail banking in Middle East: The case of Qatar. International Journal of Islamic and Middle Eastern Finance and Management, 2(4), 338-350. http://dx.doi.org/10.1108/17538390911006386

Jun, M., \& Cai, S. (2001). The key determinants of Internet banking service quality: A content analysis. International Journal of Bank Marketing, 19(7), 276-291. http://dx.doi.org/10.1108/02652320110409825

Katircioglu, S., Fethi, S., Unlucan, D., \& Dalci, I. (2011). Bank selection factors in the banking industry: An empirical investigation from potential customers in Northern Cyprus. Acta Oeconomica, 61(1), 77-89. http://dx.doi.org/10.1556/AOecon.61.2011.1.5

Kaura, V., Prasad, C., \& Sharma, S. (2015). Service quality, service convenience, price and fairness, customer loyalty, and the mediating role of customer satisfaction. International Journal of Bank Marketing, 33(4), 404-422. http://dx.doi.org/10.1108/IJBM-04-2014-0048

Malta Financial Services Authority. (2015). Annual report, Malta Financial Services Authority, Malta.

Martenson, R. (1985). Consumer choice criteria in retail bank selection. International Journal of Bank Marketing, 3(2), 64-74. http://dx.doi.org/10.1108/eb010755

Masa, R., Sherrard Sherraden, M., Zou, L., Ssewamla, F., Johnson, L., Ansong, D., Chowa, G., \& Sherraden, M. 
(2010). Youth savings around the world: Youth characteristics, savings performance, and potential effects. Working Paper, Center for Social Development, Wahsington University in St. Louis.

Meuter, M.L., Bitner, M.J., Ostrom, A.L., \& Brown, S.W. (2005). Choosing among alternative service delivery modes: An investigation of customer trial of self-service technologies. Journal of Marketing, 69(2), 61-83. http://dx.doi.org/10.1509/jmkg.69.2.61.60759

Mokhlis, S., Mat, N.H.N., \& Salleh, H.S. (2008). Commercial bank selection: Comparison between single and multiple bank users in Malaysia. International Journal of Economics and Finance, 1(2), 263-273. http://dx.doi.org/10.5539/ijef.v1n2p263

Morris, M.G., \& Venkatesh, V. (2000). Age differences in technology adoption decisions: Implications for a changing work force. Personnel Psychology, 53(2), 375-403. http://dx.doi.org/10..1111/j.1744-6570.2000.tb00206.x

Narteh, B. (2013). Determinants of students' loyalty in the Ghanaian banking industry. The TQM Journal, 25(2), 153-169. http://dx.doi.org/10.1108/17542731311299591

Narteh, B., \& Owusu-Frimpong, N. (2011). An analysis of students' knowledge and choice criteria in retail bank selection in sub-Saharan Africa: The case of Ghana. International Journal of Bank Marketing, 29(5), 373-397. http://dx.doi.org/10.1108/02652321111152909

Ndubisi, N.O., \& Wah, K.C. (2005). Factorial and discriminant analysis of the underpinnings of relationship marketing and customer satisfaction. International Journal of Bank Marketing, 23(3), 542-557. http://dx.doi.org/10.1108/02652320510629908

Paul, J., Mittal, A., \& Srivastav, G. (2016). Impact of service quality on customer satisfaction in private and public sector banks. International Journal of Bank Marketing, 34(5), 606-622. http://dx.doi.org/10.1108/IJBM-03-2015-0030

Rao, S., \& Sharma, R.K. (2010). Bank selection criteria employed by MBA students in Delhi: An empirical analysis. Journal of Business Studies Quarterly, 1(2), 56-69.

Rashid, M. (2012). Bank selection criteria in developing country: Evidence from Bangladesh. Asian Journal of Scientific Research, 5(2), 58-69. http://dx.doi.org/10.3923/ajsr.2012.58.69

Rogers, E.M. (2003). Diffusion of innovations (5th ed.). The Free Press, New York.

Saleem, M.A., Zahra, S., Ahmad, R., \& Ismail, H. (2016). Predictors of customer loyalty in the Pakistani banking industry: A moderated-mediation study. International Journal of Bank Marketing, 34(3), 411-430. http://dx.doi.org/10.1108/IJBM-12-2014-0172

Sayani, H. (2015). Customer satisfaction and loyalty in the United Arab Emirates banking industry. International Journal of Bank Marketing, 33(3), 351-375. http://dx.doi.org/10.1108/IJBM-12-2013-0148

The Master Card Foundation. (2012). What do youth savers want?, Results from market research In four countries, Save the Children Federation, Inc., Nepal. Retrieved from http://mastercardfdn.org/wp-content/uploads/YouthSave-Market-Research-Report_FINAL1.pdf

Todd, S. (2013). JP Morgan Chase to stop making student loans, American Banker [New York, N.Y] 6-September-2013.

Vyas, V., \& Raitani, S. (2014). Drivers of customers' switching behaviour in Indian banking industry. International Journal of Bank Marketing, 32(4), 321-342. http://dx.doi.org/10.1108/IJBM-04-2013-0033

Waters, A. (2006). Best banking bets. Nursing Standard, 20(33), 22-25.

World Economic Forum. (2013). Engaging tomorrow's consumer, A report by the World Economic Forum's Sustainable Consumption Initiative prepared in collaboration with Accenture. Retrieved from http://www3.weforum.org/docs/WEF_RC_EngagingTomorrowsConsumer_Report_2013.pdf

World Economic Forum. (2015). The global competitiveness report 2015-2016. Retrieved from http://reports.weforum.org/global-competitiveness-report-2015-2016/

Yavas, U., Benkenstein, M., \& Stuhldreier, U. (2004). Relationships between service quality and behavioral outcomes: A study of private bank customers in Germany. International Journal of Bank Marketing, 22(2), 144-57. http://dx.doi.org/10.1108/02652320410521737 